\title{
Accounting for the Effects of Climate Variability in Regional Flood Frequency Estimates in Western Nigeria
}

\author{
Iguniwari Thomas Ekeu-Wei ${ }^{1,2 *}$, George Alan Blackburn1 ${ }^{1}$, Jason Giovannettone ${ }^{3}$ \\ ${ }^{1}$ Lancaster Environmental Centre, Lancaster University, Lancaster, UK \\ ${ }^{2}$ Kawari Technical Services Nigeria Limited, Yenagoa, Nigeria \\ ${ }^{3}$ Dewberry, 8401 Arlington Blvd., Fairfax, Virginia, USA \\ Email: ^iguniwari@gmail.com
}

How to cite this paper: Ekeu-Wei, I.T., Blackburn, G.A. and Giovannettone, J. (2020) Accounting for the Effects of Climate Variability in Regional Flood Frequency Estimates in Western Nigeria. Journal of Water Resource and Protection, 12, 692-713.

https://doi.org/10.4236/jwarp.2020.128042

Received: June 18, 2020

Accepted: August 16, 2020

Published: August 19, 2020

Copyright $\odot 2020$ by author(s) and Scientific Research Publishing Inc. This work is licensed under the Creative Commons Attribution International License (CC BY 4.0).

http://creativecommons.org/licenses/by/4.0/

\begin{abstract}
Extreme flood events are becoming more frequent and intense in recent times, owing to climate change and other anthropogenic factors. Nigeria, the case-study for this research experiences recurrent flooding, with the most disastrous being the 2012 flood event that resulted in unprecedented damage to infrastructure, displacement of people, socio-economic disruption, and loss of lives. To mitigate and minimize the impact of such floods now and in the future, effective planning is required, underpinned by analytics based on reliable data and information. Such data are seldom available in many developing regions, owing to financial, technical, and organizational drawbacks that result in short-length and inadequate historical data that are prone to uncertainties if directly applied for flood frequency estimation. This study applies regional Flood Frequency Analysis (FFA) to curtail deficiencies in historical data, by agglomerating data from various sites with similar hydro-geomorphological characteristics and is governed by a similar probability distribution, differing only by an "index-flood"; as well as accounting for climate variability effect. Data from 17 gauging stations within the Ogun-Osun River Basin in Western Nigeria were analysed, resulting in the delineation of 3 sub-regions, of which 2 were homogeneous and 1 heterogeneous. The Generalized Logistic distribution was fitted to the annual maximum flood series for the 2 homogeneous regions to estimate flood magnitudes and the probability of occurrence while accounting for climate variability. The influence of climate variability on flood estimates in the region was linked to the Madden-Julian Oscillation (MJO) climate indices and resulted in increased flood magnitude for regional and direct flood frequency estimates varying from $0 \%$ - $35 \%$ and demonstrate that multi-decadal changes in atmospheric conditions
\end{abstract}


influence both small and large floods. The results reveal the value of considering climate variability for flood frequency analysis, especially when non-stationarity is established by homogeneity analysis.

\section{Keywords}

Climate Variability, Regional Flood Frequency, Climate-Indices, L-Moment, Madden-Julian Oscillation (MJO), Generalised Logistic (GLO), Climate-Indices

\section{Introduction}

Floods are natural hazards aggravated by both climatic factors (i.e. climate variability and climate change) and non-climatic factors (e.g. changes in land cover, use, vegetation, etc.) [1], and result in the destruction and disruption of socio-economic activities, damage to property and infrastructure, loss of lives, and financial loss [2]. In Nigeria-the case-study for this research, frequent and unprecedented levels of flooding and impacts has increased the concern from the public, government, and other stakeholders about the probability of flood recurrence, thus reinforcing the need to establish appropriate mitigation measures to minimize flood impacts [3].

Knowledge of flood frequency estimates is crucial to ensure socio-economic activities and infrastructural development are planned appropriately to improve resilience [4]. Accurate estimates of flood intensities and frequencies are also important for the design of critical infrastructure required to flood risk reduction (dykes, levees, dams, etc.), construction of hydraulic structures (bridges, culverts, drainages), the development of floodplain and urban land-use regulations, emergency management, and disaster risk insurance [5]. Under-estimating design flood could lead to increased flood risk with potentially catastrophic consequences, while over-estimation, on the other hand, could cause resource wastage and aggravate upstream and downstream flooding [6].

To accurately estimate expected flood magnitudes and return periods, networks of gauging stations are typically established to collect hydrological data over a long period. However, in many developing regions, establishing the optimal number of hydrological stations is usually hampered by challenges such as the high cost associated with gauging equipment. Therefore, several locations are usually left ungauged or contain short-length of record if the gauging stations are newly established, discontinued, or damaged. In many low/middle-income countries, many catchments are sparsely gauged due to factors that include lack of commitment by station operators; deteriorating conditions of observation equipment; insecurity/theft, and inaccessibility to remote locations [7] [8]. The absence of high-quality and sufficient data results in poor flood predictions in these areas, and consequently, flawed flood risk management interventions [9]. Therefore, it is essential to explore techniques capable of extracting maximum 
value from available data to develop robust flood frequency estimates in data-poor regions with reduced uncertainty.

Generally, the choice of a flood frequency estimation approach depends on the extent of availability of historical flood records at/or around the specific site of interest. When sufficient historical flood data are available, direct flood frequency analysis is performed by fitting a pre-defined probability distribution to the annual maximum flood or partial flood time series [10]. Where data is insufficient, indirect flood estimation procedures are used, such as the adoption of hydro-meteorological data from other locations similar in characteristics to the site of interest [11] [12] or the incorporation of data from other sources including remote sensing [13] [14]. The present study adopts the former approach.

A major factor that affects future flood regimes and must be considered when estimating flood magnitudes is the changing climate, whether characterized by shorter-term cyclical climate variability or longer-term trends related to climate change. Climate variability refers to the Spatio-temporal deviations/anomalies of climatic statistics over a given period (e.g. a month, season or year), while climate change refers to the longer-term non-cyclical trends that are projected to lead to more intense and frequent flooding [15]. Estimating flood intensities and frequencies under changing climatic conditions requires the incorporation of the effects of non-stationarity defined by statistically significant breakpoints and trends within historical time series [16] [17]. Understanding the effects of climate on extreme hydro-meteorological events in a region requires the integration of measures of climate variability such as hydro-climatic indices [18] [19]. Several studies have revealed that incorporating climatic variability into flood frequency estimation procedures result in more robust estimates [18] [19] [20].

This study aims to tackle the problem of data sparsity and limited resources to estimate flood magnitude and frequency while taking into consideration the effects of climate variability using open-source tools. The study is presented as follows: Section (2): Description of the study area, datasets and sources; Section (3): Methodology-Data preparation, preliminary analysis and L-moment statistics-based regional flood frequency techniques, taking climate variability into account (climate indices); Section (4): Presentation of the results of preliminary analysis, direct and regional flood frequency estimates and incorporating climate variability; and Section (5): Conclusion and implication of the results on flood risk management.

\section{Study Area, Datasets and Sources}

The Ogun-Osun River Basin (OORB) is in Western Nigeria $\left(6^{\circ} 30^{\prime}-8^{\circ} 20^{\prime} \mathrm{N}\right.$ latitude and $3^{\circ} 23^{\prime}-5^{\circ} 10^{\prime} \mathrm{E}$ longitude), and encompasses four states including Ogun, Osun, Oyo and Lagos, within an area of $66,264 \mathrm{~km}^{2}$. The Basin is drained by two major tributaries, the Ogun and Osun Rivers, and other minor tributaries including the Yewa, Ibu, Ona, Sasa and Ofiki Rivers, into the Lagos Lagoon (See Figure 1). 


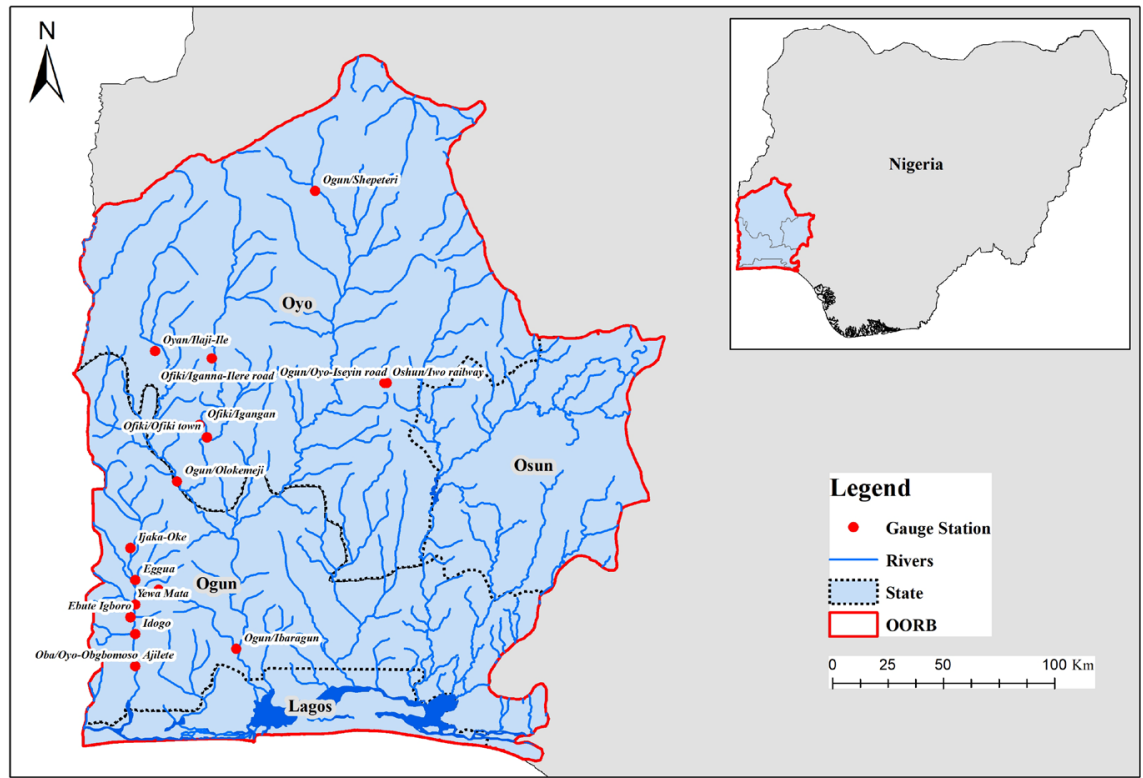

Figure 1. Study area: The Ogun-Osun River Basin (OORB), Nigeria.

The climate of the OORB is influenced by tropical continental and maritime air masses [21] and experiences an annual rainfall of $1400 \mathrm{~mm}$ to $1500 \mathrm{~mm}$; mean annual air temperature ranges from $25.7^{\circ} \mathrm{C}$ to $30^{\circ} \mathrm{C}$, and relative humidity varies from $37 \%$ to $85 \%$ [22]. OORB experiences recurring flooding caused by the increased frequency of intense precipitation events, poor urban planning and waste management practices, and failure of upstream hydraulic systems, which have led to significant socio-economic, infrastructural, ecological and environmental impacts [23]. Also, recent evidence from studies in West Africa [24] [25] [26] and Nigeria [27] suggests the presence of strong correlations between climatic variability and hydro-meteorological events in the regions.

Hydrological data (discharge, water levels and rating curves) used for this study were provided by the Ogun-Osun River Basin Development Authority (OORBDA), the agency responsible for collecting and managing data within the Basin. Additional data sets for two hydrological stations, Yewa Mata and Ona River/Sala village were extracted from published research by Olukanni and Alatise [28] and Ewemoje and Ewemooje [29] respectively, using WebPlotDigitizer tool [30]. The catchment area for each station was delineated from 30-m resolution Shuttle Radar Topography Mission (SRTM) digital elevation model data [31] using the Arc Hydro tool in ArcMap 10.2. The properties of the gauging stations for OORB are presented in Table 1, while the spatial distribution of gauging stations is presented in Figure 1, showing the spread and sparsity of the hydrological monitoring network.

Climate indices data used in this study originates from the data repository of the United States National Oceanographic and Atmospheric Administration (NOAA) [32] and are embedded within the open-source International Centre for Integrated Water Resources Management Regional Analysis of Frequency 
Table 1. Properties of OORB gauging stations.

\begin{tabular}{|c|c|c|c|c|c|c|c|}
\hline $\mathrm{S} / \mathrm{N}$ & Station Name & Years of data availability & Data points & Latitude & Longitude & Missing data & Catchment Area $\left(\mathrm{Km}^{2}\right)$ \\
\hline 1 & Eggua & $1980-2012$ & 26 & 7.05 & 2.92 & 0 & 0.64 \\
\hline 2 & Idogo & $1980-2012$ & 24 & 6.83 & 2.92 & 0 & 0.923 \\
\hline 3 & Ajilete & $1980-2012$ & 29 & 6.70 & 2.92 & 0 & 2.89 \\
\hline 4 & Oba/Oyo-Ogbomosho & $1966-1988$ & 23 & 6.70 & 2.92 & 0 & 2.90 \\
\hline 5 & Ebute Igboro & $1980-2012$ & 25 & 6.90 & 2.90 & 0 & 7.92 \\
\hline 6 & Yewa Mata & $1982-1994$ & 14 & 6.95 & 2.92 & 0 & 24.05 \\
\hline 7 & Ijaka-Oke & $1980-2012$ & 27 & 7.18 & 2.90 & 0 & 63.15 \\
\hline 8 & Ogun/Oyo-Iseyin road & $1966-1988$ & 23 & 7.85 & 3.94 & 0 & 578.00 \\
\hline 9 & Ofiki/Ofiki town & $1966-1988$ & 23 & 7.63 & 3.21 & 1 & 715.00 \\
\hline 10 & Ogun/Shepeteri & 1966-1988 & 23 & 8.63 & 3.65 & 0 & 1190.00 \\
\hline 11 & Oyan/Ilaji-Ile & $1982-2009$ & 26 & 7.98 & 3.00 & 1 & 1460.00 \\
\hline 12 & Ofiki/Iganna-Ilere road & $1966-1988$ & 23 & 7.95 & 3.23 & 0 & 3978.00 \\
\hline 13 & Ofiki/Igangan & 1966-1988 & 23 & 7.68 & 3.18 & 0 & 2732.00 \\
\hline 14 & Oshun/Iwo railway & $1965-1988$ & 24 & 7.85 & 3.93 & 0 & 4325.00 \\
\hline 15 & Ona river/Sala Village & 1982-1999 & 18 & 7.01 & 3.015 & 0 & 8500.00 \\
\hline 16 & Ogun/Olokemeji & $1966-1987$ & 22 & 7.45 & 3.09 & 0 & 9140.00 \\
\hline 17 & Ogun/Ibaragun & $1965-1988$ & 24 & 6.77 & 3.33 & 0 & $21,660.00$ \\
\hline
\end{tabular}

Tool (ICI-RAFT). This data includes multi-decadal hydro-climate indices such as the Pacific Decadal Oscillation, El Nino/Southern Oscillation, Madden Julian Oscillation, North Atlantic Oscillation and others. As a data limitation, it is important to note the variation in the period of data availability for the respective sites restricts the direct comparison of sites for analytical purposes.

\section{Methodology}

\subsection{Data Preparation and Preliminary Analysis}

Prerequisite data preparation undertaken includes data formatting and conversion, infilling of missing data and statistical testing. First, historical river water level data were converted to discharge using available up-to-date rating curves provided by the OORBDA. Multiple imputation techniques based on coupled Markov Chain Monte Carlo and ordinary least squares regression is applied using Microsoft XLSTAT tool to fill the gaps to approximate missing peak annual discharge (flood) [33]. FFA application typically assumes that available data satisfies conditions of randomness, serial non-correlation, the absence of outliers, and homogeneity, to reduce the inherent data uncertainty [10].

The randomness of hydrologic data points at each station is estimated using the Mann-Kendall (M-K) test [34], which assesses the increasing and decreasing trends in the time series [35]. The presence of serial correlation within hydrological records at a particular site results in discrepancies in regional variance 
and increased data skewness [36], thus contributing to uncertainty in regional flood frequency estimates [4]. To assess the magnitude of the serial correlation, 1-unit Lag correlation coefficients [17] are applied to derive values ranging from -1 (perfect non-correlation) to 1 (perfect correlation). The presence of outliers also affects data quality and can be attributed to gauge failure, sampling inconsistencies, typo errors, or gauge disruptions; they are not considered part of the real flood population [37]. Outliers were identified by using the Grubbs and Beck test [38]. Finally, breakpoint analysis [16] is applied to assess significant homogeneity within the hydrological time series.

\subsection{Climate Indices-Assessing Climate Variability Effect on Flood Frequency Estimates}

Climate variability depicts the pattern of climate dynamics on both temporal and spatial scales, identified as fluctuation above or below the average climate pattern for a short period, thus influencing the magnitude and frequency of extreme flood events [39] [40]. While past hydrologic models have assumed stationarity, current climatic conditions suggest that the future is expected to differ despite what is known of the past and present [41]. Ocean-atmosphere processes that influence precipitation, atmospheric pressure and temperature are defined by climatic indices and are useful in tracking long-term decadal hydrological changes [42] [43]. Some key climate indices that characterize the frequency, intensity and duration of extreme climatic events include the Arctic Oscillation (AO), North Pacific Oscillation (NPO), North Atlantic Oscillation (NAO), Pacific Decadal Oscillation (PDO), Pacific/North American Index (PNA), El Nino/Southern Oscillation (ENSO), and Madden-Julian Oscillation (MJO) [24].

In this study, the correlation between the annual maximum discharge time-series and climatic indices are evaluated as an indicator of climate variability influence on flood magnitude and frequencies [19] [43]. ICI-RAFT developed by Giovannettone and Wright, [44] contains a database of 30 hydro-climate indices (HCI), including those previously mentioned, to facilitate correlation analysis, taking into account a stipulated Lag, as well as lower and upper index limits. To consider climate variability influence on flood frequency analysis, the ICI-RAFT program recomputes flood magnitude for each return period using only non-zero data that satisfies the index limits set for the HCI with the highest correlation coefficient $\left(\mathrm{R}^{2}\right)[44]$.

\subsection{L-Moment-Index Flood Regional Flood Frequency Analysis (RFFA)}

Regional flood frequency analysis is based on the agglomeration of hydrological data from homogeneous regions characterised by similar physiographical parameters (e.g. catchment area, catchment slope, stream length, precipitation, and elevation). Hydrological data available at sites within a defined region are used to estimate the regional flood quantile based on the assumption that they are defined by the same probability distribution and differ only by the index flood [4]. 
This approach helps reduce inconsistencies associated with data shortage [6].

The Index flood technique developed by Dalrymple [45] has been widely applied in determining flood estimates for gauged and ungauged catchments of varying sizes at the global, regional and local scales [13] [46] [47]. The general assumption for this method is that the probability distribution of the annual maximum floods across sites in the region are similar and differ only by a site-specific scaling factor termed the index flood (mean or median flood) [4] [45]. The flood quantile $\left(Q_{T}\right)$ for a $T$-year return period at a site of interest (i), given a common regional probability distribution factor $\left(X_{T}\right)$, can be mathematically expressed as:

$$
Q_{T(i)}=\left(Q_{\text {index }}\right) X_{T}
$$

The index-flood ( $\left.Q_{\text {index }}\right)$ for an ungauged site of interest is usually derived from establishing a relationship between available catchment characteristic (such as catchment area, elevation, annual precipitation, etc.) and the index-flood of gauged sites within a homogeneous region [48]. The regional probability distribution is a dimensionless parameter determined using a best-fit statistical approach discussed later in Section 3.3.3.

L-moment based flood frequency analysis was undertaken using ICI-RAFT [44], and the procedure includes 1) data screening and site clustering to derive discordancy measure (D) based on the Wards hierarchical clustering approach, 2) regional homogeneity testing using the heterogeneity measure (H), and 3) selection of the appropriate distribution using the goodness-of-fit measure $(Z)$ [4]. The L-moments is a widely-preferred method for regional flood frequency analysis due to the robustness of linear moments in comparison to ordinary moments in handling extreme values over a wider range of probability distributions and its reduced susceptibility to bias. The components of L-moment analysis are detailed in Hosking and Wallis [4] and other studies [49] and are summarized below.

\subsubsection{Data Screening}

The discordancy measure based on L-Moments (L-Mean, L-Covariance, L-Kurtosis and L-Skewness) is applied to identify sites whose L-Moment ratio are discordant from that of the whole group, denoted by a critical value of $(D \geq 3)$. Where, $\mathrm{L}$-mean is similar to conventional mean, defined as a measure of central tendency; L-Covariance is defined as a dimensionless measure of variability, ranging from low (0) to very high (0.4) variability; L-Skewness ( $\mathrm{t} 3$ ) is a measure of the degree of symmetry of a sample. L-Skewness value typically lies between -1 and $+1, \mathrm{t} 3=0$ suggests symmetric distribution. L-Kurtosis ( $\mathrm{t} 4)$, is a measure of peakedness or the flatness of the frequency distribution curve near its centre. Formulas that define L-moment statistics are presented in Hosking and Wallis [4].

\subsubsection{Homogeneity Testing}

Heterogeneity measure $(\mathrm{H})$ compares the variation between L-moments for a group of sites and what is expected of a homogeneous region to justify that a 
group of sites are defined by a similar probability distribution. The region is deemed acceptably homogeneous if $\mathrm{H}<1$, possibly heterogeneous if $1 \leq \mathrm{H}<2$, and heterogeneous if $\mathrm{H} \geq 2$ [4].

\subsubsection{Probability Distribution Selection}

The Z-Statistic is a goodness-of-fit measure that assesses the probability distribution that best fits the weighted-average regional L-moment parameters of each site in a homogeneous region (L-Skewness and L-Kurtosis). A preliminary probability distribution can also be approximated and visualized using an L-moment diagram (L-Kurtosis vs. L-Skewness), with the best distribution defined as the distribution curve closest to the majority of the sample data points [50].

\section{Results and Discussion}

\subsection{Data Characteristics and Preliminary Analysis}

Data preparation results are presented in Table 2. The 1-unit Lag correlation results show that the serial correlation between data sets at each site varied from -0.002 to $0.516(-1=$ perfect inverse correlation; $1=$ perfect correlation; and $0=$ no correlation), suggesting the absence of a strong relationship among peak annual discharge at each site. Grubbs and Beck test detected no low outlier, but high

Table 2. Results of preliminary analysis.

\begin{tabular}{|c|c|c|c|c|c|c|}
\hline $\mathrm{S} / \mathrm{N}$ & Station name & Data points & Outlier & Trend (+/-) & Homogeneity & 1-unit Lag correlation \\
\hline 1 & Ijaka-Oke & 33 & 0.464 & $0.001(+)$ & 0.081 & 0.516 \\
\hline 2 & Eggua & 33 & 0.017 & $0.721(+)$ & 0.149 & 0.083 \\
\hline 3 & Ebute Igboro & 33 & 0.005 & $0.420(+)$ & 0.193 & 0.083 \\
\hline 4 & Idogo & 33 & 0.001 & $0.768(+)$ & 0.776 & 0.330 \\
\hline 5 & Ajilete & 33 & 0.016 & $0.457(-)$ & 0.290 & -0.025 \\
\hline 6 & Yewa Mata & 14 & 0.049 & $0.518(-)$ & 0.885 & -0.209 \\
\hline 7 & Oyan/Ilaji-Ile & 26 & 0.838 & $0.000(-)$ & 0.548 & 0.319 \\
\hline 8 & Ona river & 18 & 0.955 & $0.654(-)$ & 0.439 & 0.019 \\
\hline 9 & Oshun/Iwo railway & 24 & 0.061 & $0.132(+)$ & 0.189 & 0.305 \\
\hline 10 & Oba/Oyo-Ogbomosho & 23 & 0.298 & $0.016(+)$ & 0.001 & 0.272 \\
\hline 11 & Ofiki/Ofiki town & 23 & 0.128 & $0.566(+)$ & 0.659 & -0.254 \\
\hline 12 & Ofiki/Iganna-Ilere road & 23 & 0.370 & $0.057(+)$ & 0.013 & 0.302 \\
\hline 13 & Ofiki/Igangan & 23 & 0.398 & $0.057(+)$ & 0.047 & 0.274 \\
\hline 14 & Ogun/Shepeteri & 23 & 0.079 & $0.172(+)$ & 0.183 & -0.164 \\
\hline 15 & Ogun/Oyo-Iseyin road & 23 & 0.312 & $0.566(+)$ & 0.444 & 0.125 \\
\hline 16 & Ogun/Ibaragun & 24 & 0.279 & $0.472(+)$ & 0.463 & -0.018 \\
\hline 17 & Ogun/Olokemeji & 22 & 0.000 & $0.617(-)$ & 0.170 & 0.077 \\
\hline
\end{tabular}

Outliers and Homogeneity presented as p-values. 


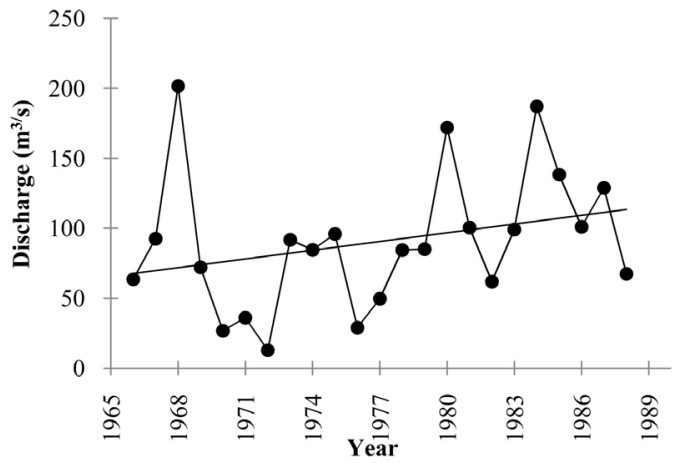

(a)

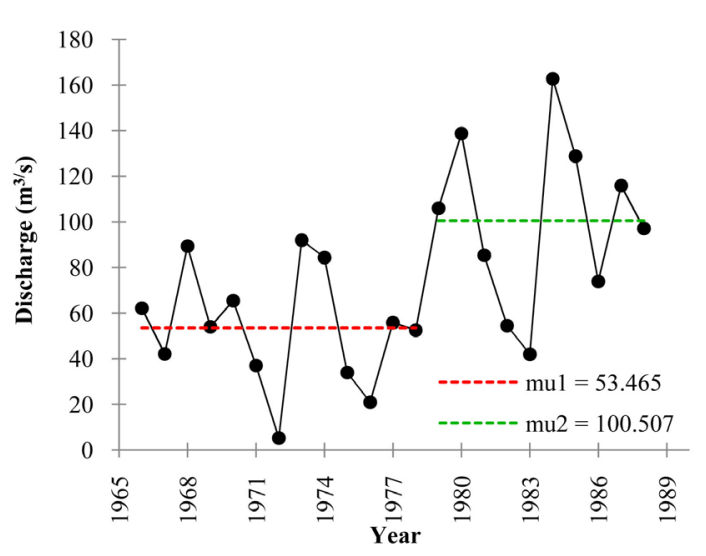

(c) outliers observed at Oba/Oyo-Ogbomosho, Ofiki/Ofiki town, Ofiki/Iganna-Ilere road, Ofiki/Igangan, Ogun/Shepeteri, Ogun/Oyo-Iseyin road, and Ogun/Ibaragun gauging stations were consistent with recorded flood events reported in previous studies [28]. Trend and breakpoint analysis (homogeneity test) results revealed significant upward trends at Ijaka-Oke, Oyan/Ilaji-Ile, and Oba/Oyo-Ogbomosho stations, while no significant trends were identified at the remaining sites. These trends were consistent with those of the neighbouring Oueme River Basin in the Benin Republic, which is influenced by similar climatic conditions [19]. The time series plots presented in Figures 2(a)-(d) show the annual maximum discharge of selected stations for further analysis. These selections capture the varying spectrum of trends, displaying spikes and troughs that represent flood variability at Ijaka-Oke and Ofiki-Igangan (Figure 2(a) \& Figure 2(b)). Changes in hydrologic regimes defined by the breakpoint analysis were found at Ofiki/Iganna-Ilere road and Oba/Oyo-Ogbomosho stations and are presented in Figure 2(c) \& Figure 2(d). Changes in the hydrological regime are evident in the breakpoint analysis plots from 1965 to 1957 and 1979 to 1988 , corresponding to documented years of changes in precipitation patterns in Nigeria and West Africa that suggest intense drought to rainfall zone transitions [25] [51].
Figure 2. Trend and breakpoint plots for selected gauging stations at (a) Ijaka-Oke, (b) Ofiki-Igangan, (c) Ofi$\mathrm{ki} /$ Iganna-Ilere road, and $(\mathrm{d})$ Oba/Oyo-Ogbomosho. Where: $\mathrm{mu}_{1}(---)$ and $\mathrm{mu}_{2}(---)$ represent the mean discharge of both breakpoints, representing the average difference in hydrological regimes. 


\subsection{Identification of Homogeneous Regions and Determination of Discordancy Measure}

Regional discordancy (D) and heterogeneity $(\mathrm{H})$ statistics are presented in Table 3 , while site-specific results of the same statistics for sites within each sub-region are presented in Table 4. An $\mathrm{H}$-statistic of 8.89 (i.e. $\mathrm{H}>1$ ) was realized for the entire catchment area, suggesting heterogeneity [52]. Consequently, the region was divided into three sub-regions and tested for homogeneity (Table 3); the resulting L-moment statistics and discordancy of sites constituting each sub-region are presented in Table 4. The H-Statistics for sub-regions 2 and 3 showed homogeneity $(H<1)$, while sub-region 1 exhibited heterogeneity $(H>>1)$. In terms of discordancy, only Idogo was discordant $(\mathrm{D}=4.2232)$ and, therefore,

Table 3. L-moments and Homogeneity statistics per sub-region.

\begin{tabular}{ccccccccc}
\hline Region & No of Stations & Mean & L-CV & L-Skew & L-Kurt & Dis. (D) & H & Homogeneity \\
\hline All & 17 & 66.144 & 0.252 & 0.146 & 0.198 & 3.000 & 8.89 & Heterogeneous \\
1 & 6 & 35.458 & 0.224 & 0.112 & 0.226 & 0.165 & 12.42 & Heterogeneous \\
2 & 5 & 70.680 & 0.248 & 0.180 & 0.172 & 1.333 & 0.62 & Homogeneous \\
3 & 6 & 98.865 & 0.275 & 0.175 & 0.171 & 1.648 & 0.87 & Homogeneous \\
\hline
\end{tabular}

$\mathrm{L}=$ Linear, $\mathrm{CV}=$ Covariance, Skew $=$ Skewness, Kurt $=$ Kurtosis, Dis $=$ Discordancy, $\mathrm{H}=$ Heterogeneity statistic.

Table 4. L-moment and discordancy statistics for gauging stations per sub-region.

\begin{tabular}{|c|c|c|c|c|c|c|c|}
\hline Region & Station ID & Mean & $\mathrm{L}-\mathrm{CV}$ & L-Skew. & L-Kurt. & LM-ratio & Dis $(D)$ \\
\hline \multirow{6}{*}{1} & Eggua & 7.965 & 0.456 & 0.449 & 0.296 & 0.134 & 1.587 \\
\hline & Ebute Igboro & 17.312 & 0.219 & 0.189 & 0.235 & 0.114 & 0.279 \\
\hline & Ajilete & 31.219 & 0.120 & 0.176 & 0.229 & 0.129 & 0.854 \\
\hline & $\operatorname{Idog} 0^{*}$ & 11.905 & 0.049 & -0.434 & 0.276 & -0.211 & 4.223 \\
\hline & Yewa Mata & 10.203 & 0.461 & 0.352 & 0.159 & 0.143 & 1.264 \\
\hline & Ona river/Sasa Village & 189.723 & 0.137 & 0.053 & 0.033 & 0.016 & 0.667 \\
\hline \multirow{5}{*}{2} & Ijaka-Oke & 5.613 & 0.234 & 0.236 & 0.178 & 0.021 & 0.633 \\
\hline & Oshun/Iwo railway & 200.474 & 0.218 & 0.169 & 0.163 & 0.111 & 0.808 \\
\hline & Oba/Oyo-Ogbomosho & 20.808 & 0.209 & 0.132 & 0.198 & 0.058 & 0.532 \\
\hline & Ogun/Shepeteri & 17.822 & 0.261 & 0.128 & 0.238 & -0.018 & 2.09 \\
\hline & Ogun/Oyo-Iseyin road & 131.331 & 0.322 & 0.213 & 0.078 & -0.022 & 1.462 \\
\hline \multirow{6}{*}{3} & Oyan/Ilaji-Ile & 13.691 & 0.293 & 0.026 & 0.125 & -0.034 & 1.364 \\
\hline & Ofiki/Ofiki town & 16.270 & 0.253 & 0.185 & 0.159 & 0.032 & 0.335 \\
\hline & Ofiki/Iganna-Ilere road & 73.918 & 0.303 & 0.116 & 0.129 & 0.001 & 0.434 \\
\hline & Ofiki/Igangan & 90.501 & 0.305 & 0.142 & 0.203 & 0.059 & 1.382 \\
\hline & Ogun/Ibaragun & 190.916 & 0.216 & 0.041 & 0.187 & -0.044 & 0.975 \\
\hline & Ogun/Olokemeji & 218.108 & 0.359 & 0.455 & 0.346 & 0.188 & 0.667 \\
\hline
\end{tabular}


was removed from further analysis. The discordancy of other sites in the homogeneous sub-regions was within the prescribed critical limit of $\mathrm{D}<3$.

The agglomeration of historical data within the homogeneous sub-regions resulted in improved data availability for flood magnitude estimation, i.e. a combined 126 data points (sub-region 2) and 141 data points (sub-regions 3), thus exceeding the 30 years data length required for regional FFA in Nigeria, according to the Technical Guidelines on Soil Erosion, Flood and Coastal Zone Management [53].

\subsection{Regional Distribution and Goodness of Fit Measures}

The L-Moment ratio diagram (Figure 3) displays the relationship between

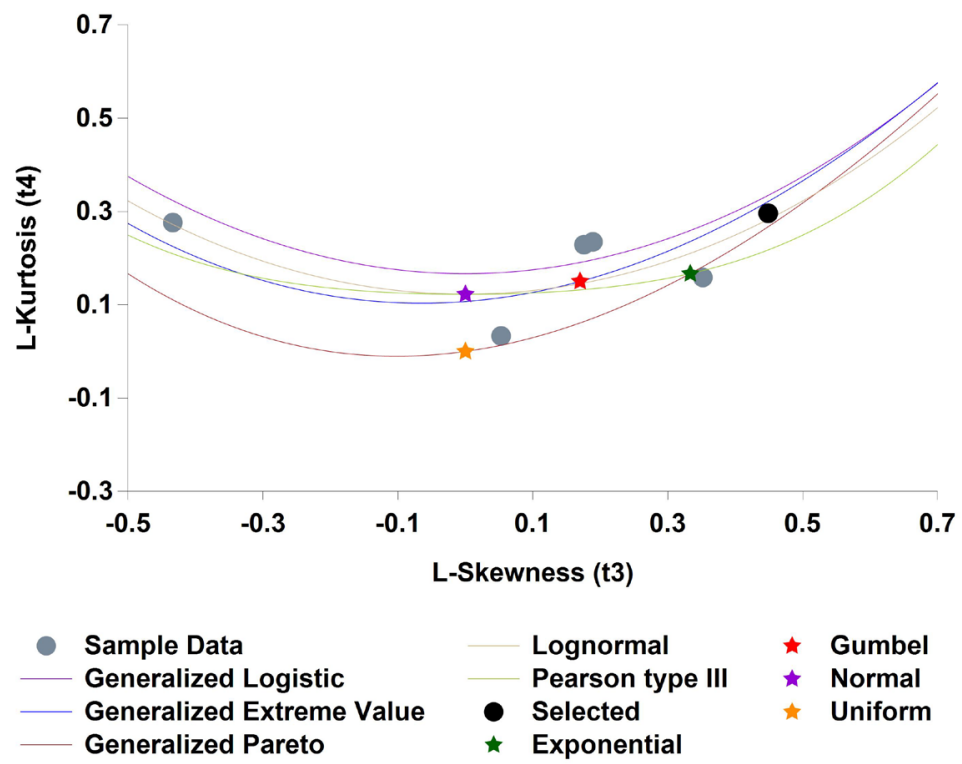

(a)

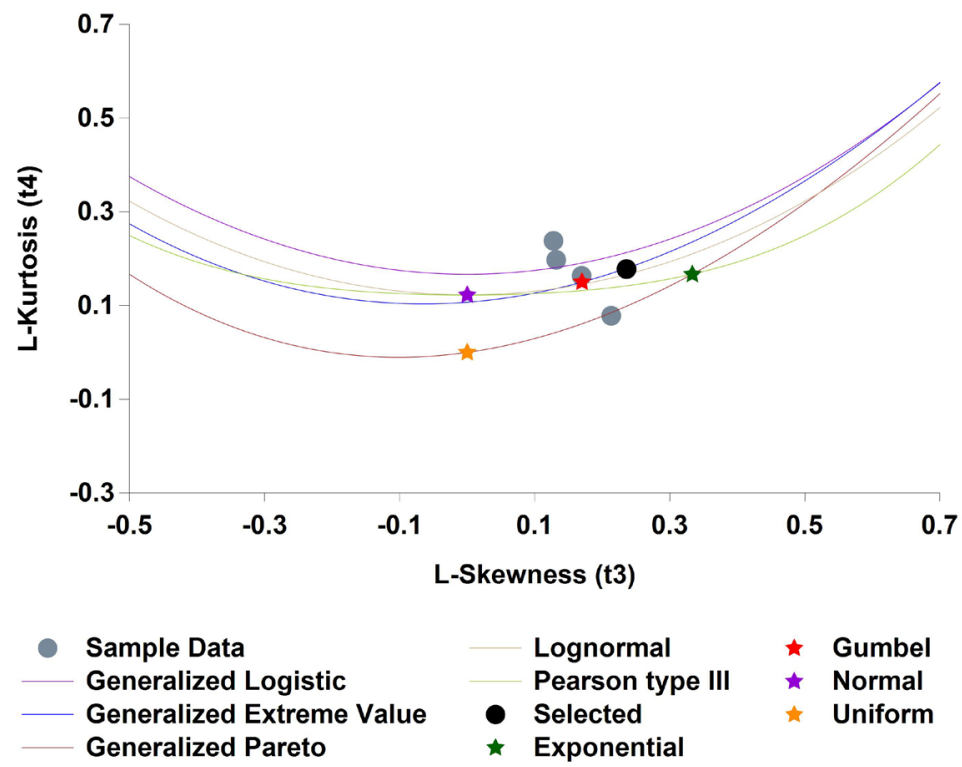

(b) 


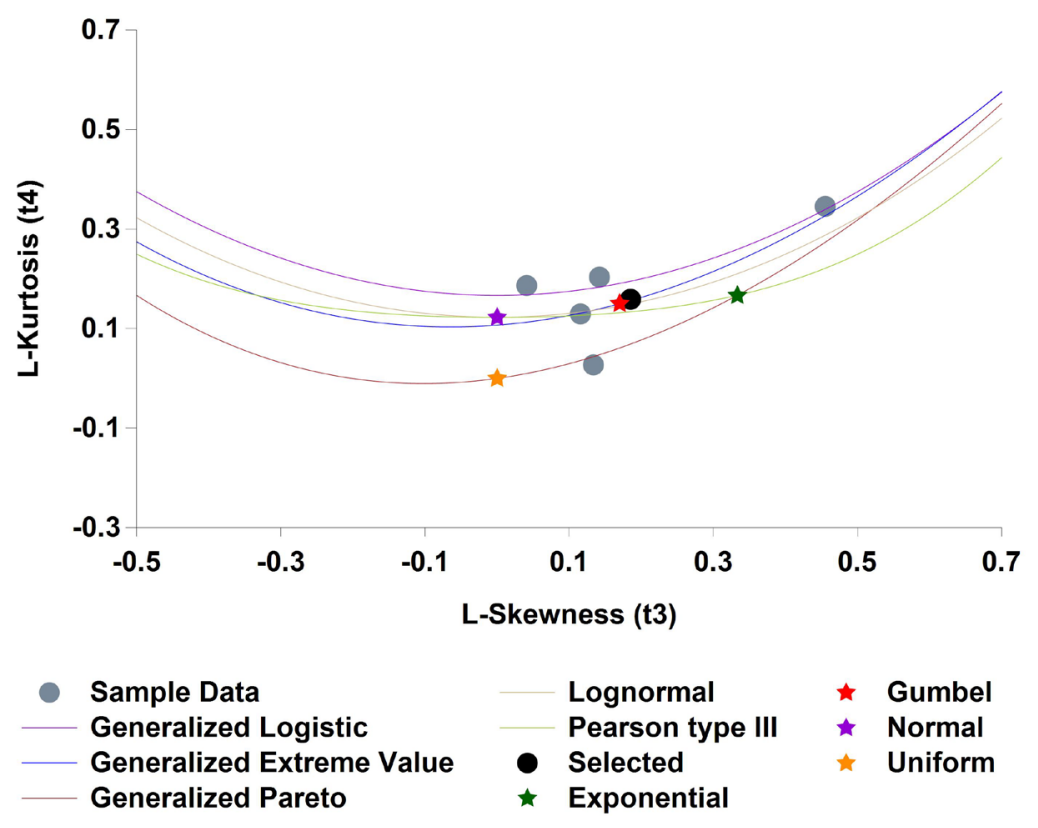

(c)

Figure 3. L-Moment ratio diagram for the three (3) sub-regions. (a) Region 1; (b) Region 2; (c) Region 3.

regional average L-skewness and L-kurtosis fitted to varying probability distributions for all three regions. The 3-parameter distribution line/curve closest to L-moment ratio points of sub-regional sites portrays an initial deduction concerning an optimal distribution [10] [54]; in this case, the Generalized Logistic (GLO) curve satisfies this approximation. A 3-parameter distribution is selected instead of its 2-parameter counterpart due to its robustness and ability to optimally represent the probability distribution parameters [55].

In addition to L-Moment ratio diagram, $Z$ Statistics provides a viable statistical approach to identify the optimal distribution that best fits the data for each sub-region. Table 5 shows the $Z$ Statistics for all distributions for each sub-region and reveals that GLO is the most significant at a $90 \%$ confidence interval $(Z \leq$ |1.64|) as prescribed by Hosking and Wallis [4] for regions 2 and 3. The result is consistent with deductions from the L-Moment Ration diagram.

The identified optimal probability distribution corresponds with those applied in previous single-site and regional studies undertaken for catchment areas close to our study area [49] [50]. The insignificance of the probability distribution for all combined sites and region $1(Z>1.65)$ suggests that all individual sites within this region are not defined by the same particular distribution due to their apparent heterogeneity.

\subsection{Regional Flood Frequency and Parameter Estimation}

After identifying GLO as the optimal probability distribution for regions 2 and 3, a flood frequency relationship was established to derive flood magnitudes. The GLO probability distribution function is given by: 
Table 5. Region clusters and $Z$ statistics for a selection of an optimal probability distributions.

\begin{tabular}{cccc}
\hline Region & LNO & GEV & GLO \\
\hline All & -3.97 & -3.44 & -1.45 \\
1 & -4.69 & -4.58 & -3.13 \\
2 & -1.83 & -0.50 & $0.49_{\mathrm{a}}$ \\
3 & -3.27 & -1.31 & -0.23 \\
\hline
\end{tabular}

$\mathrm{a}=$ optimal distribution

$$
f(x)=\frac{\alpha^{-1} \exp (-(1-k) y)}{(1+\exp (-y))^{2}}, y=\left\{\begin{array}{cc}
-k^{-1} \ln \left(1-\frac{k(x-\xi)}{\alpha}\right) & k \neq 0 \\
\frac{x-\xi}{\alpha} & k=0
\end{array}\right.
$$

where $\xi, \alpha$ and $k$ depict the location, scale and shape parameters, respectively [4].

The range of $x$ is defined as $-\infty<x \leq \xi+\frac{\alpha}{k}$ if $k>0-\infty<x<\infty$; If $k=0$; $\xi+\frac{\alpha}{k} \leq x<\infty$ if $K<0$.

The location parameter $(\xi)$ dictates the position of the distribution about a symmetric axis, the scale parameter $(\alpha)$ define the distribution spread, and the shape parameter $(k)$ indicates the behaviour of the upper tail of the distribution. These parameters are derived from L-moments and applied to derive $T$-year flood exceedance based on the GLO $\left(X_{T}\right)$ defined by:

$$
X_{T}=\xi+\frac{\alpha}{k}\left(1-(T-1)^{-k}\right)=\xi\left[1+\frac{\beta}{k}\left(1-(T-1)^{-k}\right)\right]=\xi Z_{T}
$$

where: $\beta=\alpha / \xi, T$ is the return period and $Z_{T}$ is the growth curve of $T$.

GLO distribution parameters estimated for each sub-region using L-moments were substituted into Equation (3) to estimate the sub-regional growth factors for ungauged and sparsely gauged basins and are presented in Table 6.

\subsection{Climate Indices Correlation with Peak Annual Discharge}

Ijaka-Oke, Oba/Oyo-Ogbomosho, Ofiki/Igangan-Ilere road and Ofiki-Igangan were identified by breakpoints and trend analysis to be heterogeneous and were further investigated to ascertain the influence of climate variability by correlating peak annual discharge and global climate indices. Regional and direct flood frequency estimates were then determined in ICI-RAFT using the highest correlated indices.

The Madden-Julian Oscillation (MJO) demonstrated the highest correlation with the annual maximum flood time series for the four sites (Figure 4) using an optimal lag time of 1 month (Climate Index Lag), considering that only single peak discharge values for each year were applied in the analysis. Correlation coefficients $\left(\mathrm{R}^{2}\right)$ based on MJO phase 7 which originates from the Western 
Table 6. Region clusters and parameters for the selected distribution functions.

\begin{tabular}{cccccc}
\hline Region & Distribution & $\xi$ & $\alpha$ & $k$ & Sub-region Growth Factor \\
\hline 1 & GLO & 0.959 & 0.219 & -0.112 & $0.959+\frac{0.2197}{-0.1123}\left(1-(T-1)^{-(-0.112)}\right)$ \\
2 & GLO & 0.928 & 0.235 & -0.180 & $0.928+\frac{0.2345}{-0.1803}\left(1-(T-1)^{-(-0.180)}\right)$ \\
3 & GLO & 0.922 & 0.261 & -0.175 & $0.922+\frac{0.261}{-0.175}\left(1-(T-1)^{-(-0.175)}\right)$ \\
\hline
\end{tabular}

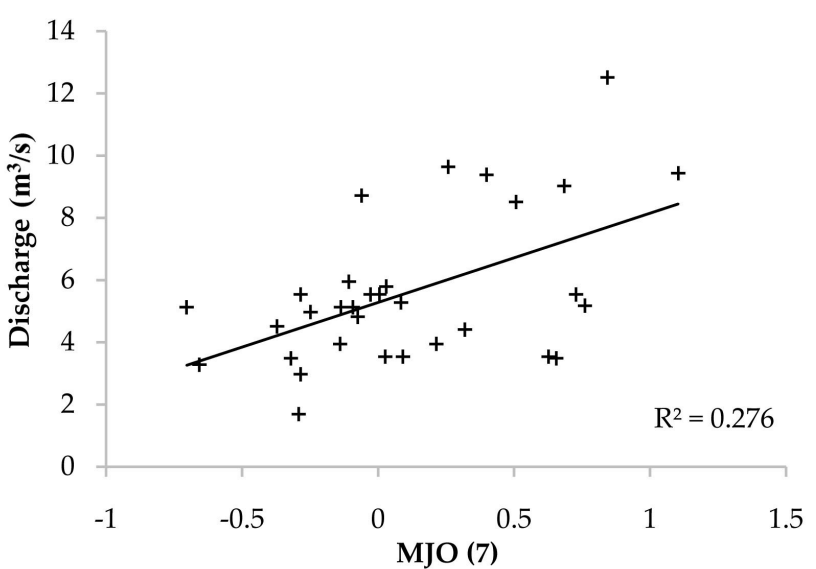

(a)

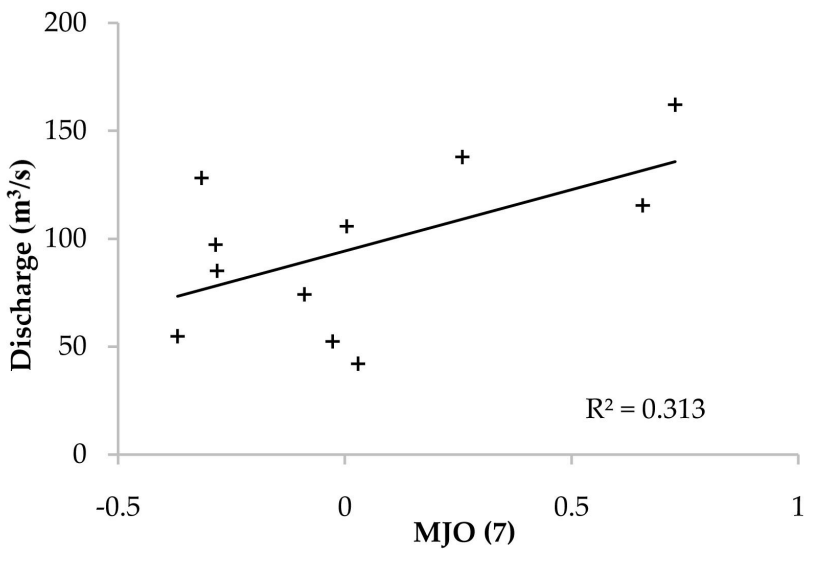

(c)

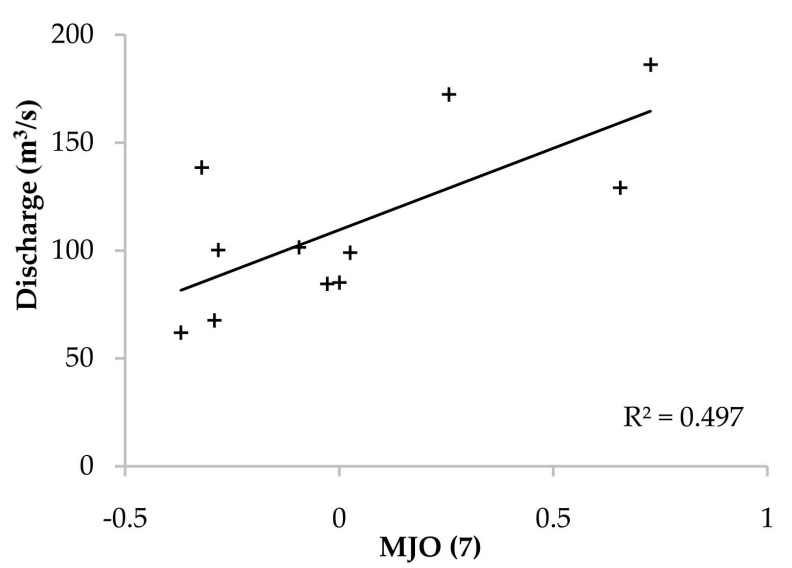

(b)

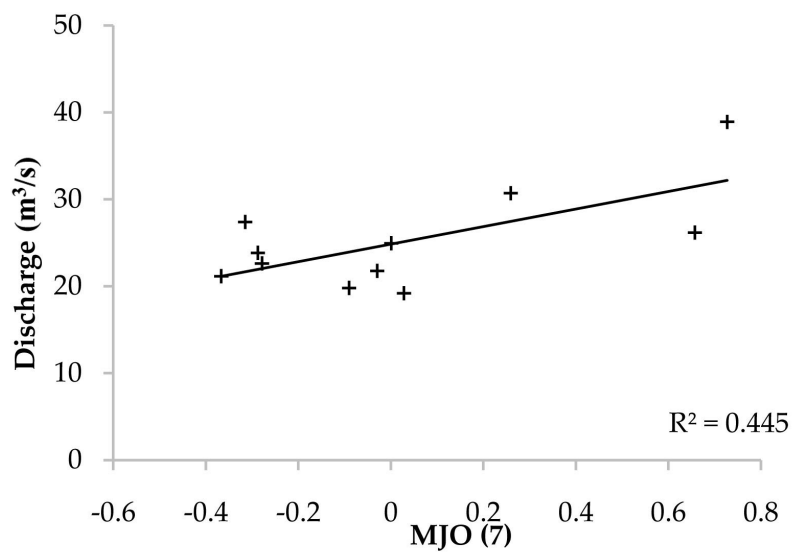

(d)

Figure 4. Plots showing the relationship between climate-indices and peak annual discharge for selected gauging stations. (a) Ijaka-Oka; (b) Ofiki-Igangan; (c) Ofiki/Igangan-Ilere road; (d) Oba/Oyo-Ogbomosho.

Pacific (longitude 40W) were $0.27,0.500 .31$ and 0.45 for Ijaka-Oke, Ofiki Igangan, Ofiki/Igangan-Ilere road and Oba/Oyo-Ogbomosho, respectively, suggesting that between 27 to 50 percent of the variability in the annual maximum flood series is attributable to climate dynamics. The correlation values derived in this study were consistent with those revealed in other studies [20]. The remaining variability in peak annual discharge can be linked factors such as local catchment properties, land use/cover changes and hydrodynamics [56] [57], which is beyond the scope of this study. 
MJO is known to be a strong driver of rainfall variability in tropical regions [58], governing atmospheric pressure and temperature around the equator. The MJO significantly influences regional rainfall [59] [60] and was reported to have influenced the rainfall dynamics that triggered the unprecedented 2012 flood event in Nigeria [61]. Arnold et al., [62] and Caballero and Huber, [63] further suggested that, due to the dependence of MJO on Sea Surface Temperature (SST) and Outgoing Longwave Radiation (OLR), MJO activities may increase in response to global warming, resulting in more frequent $\mathrm{MJO}$-influenced flood events.

\subsection{Climate Variability Effect and Flood Quantile Estimation}

Results presented in Table 7 and Figure 5 show flood frequency estimates derived when all available data points for the hydrological time series are used for regional and direct flood frequency estimation, as well as when data points that correlate and satisfies the limits set for the MJO climate variability index are used, thus accounting for the influence of climate variability. These results suggest

Table 7. Flood frequency estimates per return period (regional and Direct, and considering climate variability).

\begin{tabular}{|c|c|c|c|c|c|}
\hline \multirow{2}{*}{$\begin{array}{c}\text { Station Name } \\
\text { Ijaka-Oke }\end{array}$} & \multicolumn{5}{|c|}{ Return period (1-in-year) } \\
\hline & 2 & 5 & 20 & 50 & 100 \\
\hline Regional/Climate variability & 5 & 7 & 9 & 11 & 17 \\
\hline Regional & 5 & 7 & 10 & 13 & 15 \\
\hline Direct/Climate variability & 5 & 7 & 10 & 13 & 15 \\
\hline Direct & 5 & 7 & 10 & 13 & 15 \\
\hline Oba/Oyo-Ogbomosho & 2 & 5 & 20 & 50 & 100 \\
\hline Regional/Climate variability & 24 & 31 & 41 & 47 & 52 \\
\hline Regional & 19 & 27 & 38 & 47 & 54 \\
\hline Direct/Climate variability & 24 & 28 & 36 & 44 & 52 \\
\hline Direct & 20 & 26 & 35 & 41 & 47 \\
\hline Ofiki/Igangan-Ilere road & 2 & 5 & 20 & 50 & 100 \\
\hline Regional/Climate variability & 95 & 123 & 157 & 179 & 196 \\
\hline Regional & 70 & 98 & 136 & 163 & 185 \\
\hline Direct/Climate variability & 94 & 127 & 168 & 194 & 214 \\
\hline Direct & 70 & 103 & 147 & 177 & 203 \\
\hline Ofiki-Igangan & 2 & 5 & 20 & 50 & 100 \\
\hline Regional/Climate variability & 110 & 143 & 182 & 207 & 227 \\
\hline Regional & 86 & 120 & 167 & 200 & 227 \\
\hline Direct/Climate variability & 103 & 138 & 193 & 237 & 276 \\
\hline Direct & 84 & 125 & 182 & 223 & 257 \\
\hline
\end{tabular}

Unit of flood magnitude $=\mathrm{m}^{3} / \mathrm{s}$. 


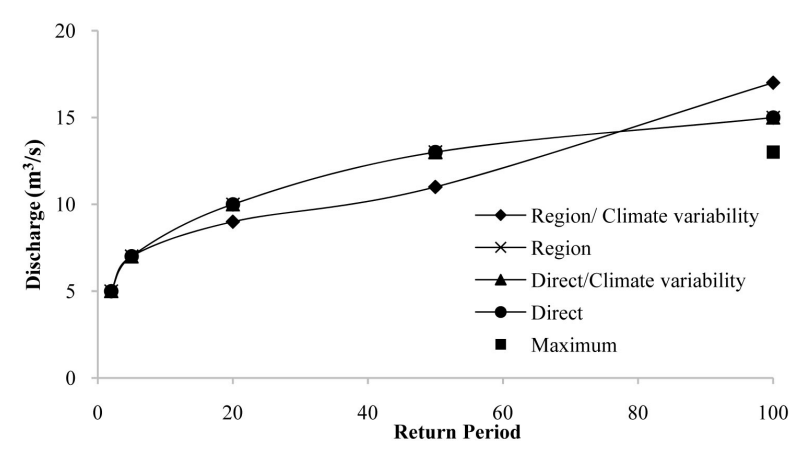

(a)

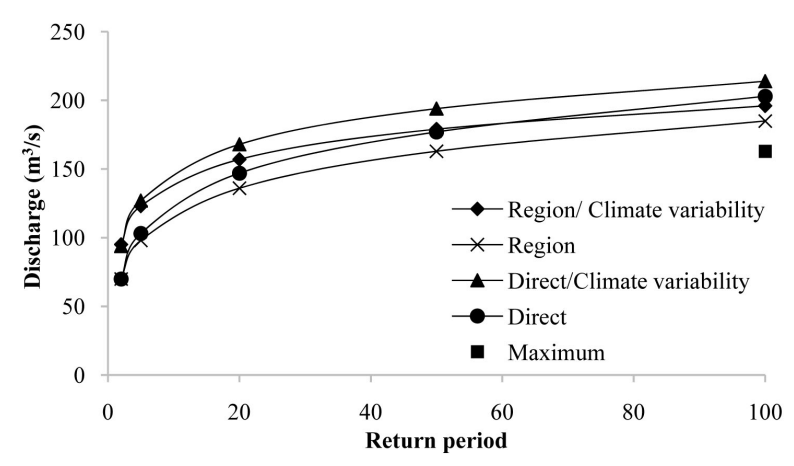

(c)

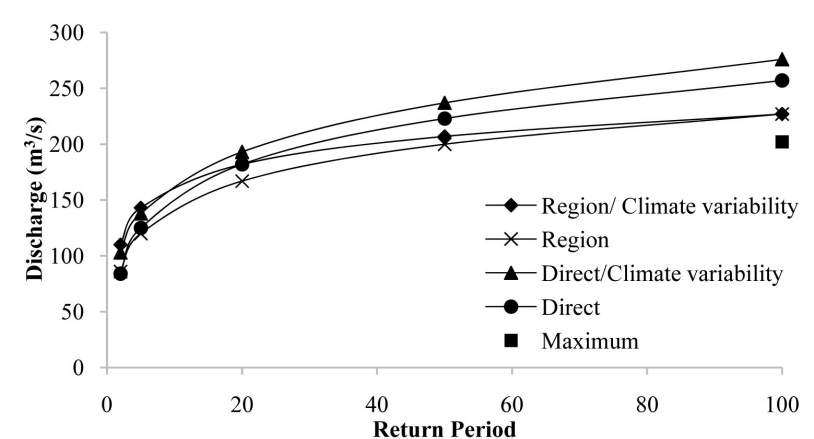

(b)

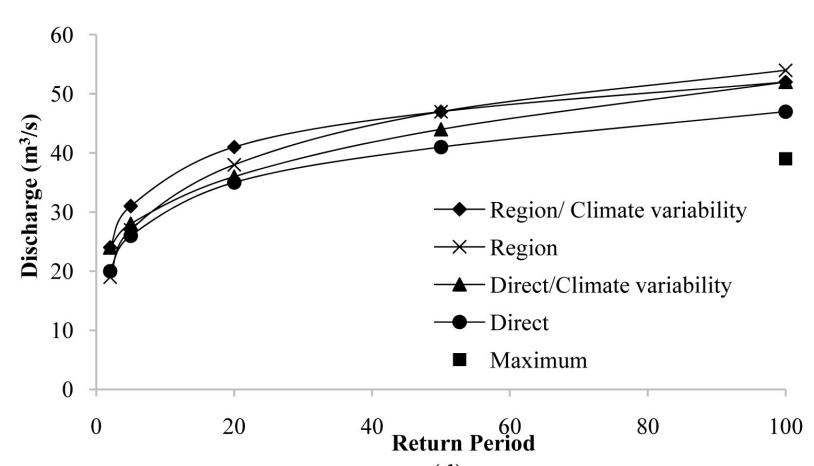

(d)

Figure 5. Flood frequency plots of regional and direct flood frequency analysis taking climate variability into account. (a) Ijaka-Oke; (b) Ofiki-Igangan; (c) Ofiki/Igangan-Ilere road; (d) Oba/Oyo-Ogbomosho.

that climate variability accounted for increased flood magnitude for regional and direct flood estimates varying from $0 \%-35 \%$, and demonstrate that multi-decadal changes in ocean-atmosphere conditions can influence both small and larger floods [63]. Also, the influence of climate variability was most evident at sites that exhibited a higher correlation with HCI (i.e. Ofiki Igangan, Ofiki/Igangan-Ilere road and Oba/Oyo-Ogbomosho). These results are generally consistent with those revealed by other studies where flood estimates that accounted for climate variability were higher than those estimated under the assumption of stationarity [65].

The criss-cross plot pattern observed at Ijaka-Oke for the inclusion of climate variability in regional flood frequency estimation suggests that caution must be taken when integrating climate variability into FFA [65], especially when the relationship between climate indices is low $\left(R^{2}=0.28\right)$. Additionally, the significance of the homogeneity rather than trends is identified as the key indicator of nonstationarity [66], as evident at the Ijaka-Oke gauging station (p-values: trend $=0.001$, homogeneity $=0.081$ ).

Furthermore, Figure 4 reveals that the historical maximum flood experienced at each site in the OORB is less than the 1-in-100 year flood guideline stipulated for flood management planning in Nigeria [53]. Thereby reinforcing the need to implement flood management measures (both structural and non-structural) based on a 1-in-100 year to curtail recurring flood impacts. 


\section{Conclusions}

The impact of flooding in Nigeria has increased over the last two decades, resulting in the displacement of persons, disruption of socio-economic activities, damage of infrastructures and loss of lives. Therefore, efficient flood risk management is urgently needed to reduce the vulnerability and exposure of the local population and assets. Flood frequency analysis is usually the first step towards flood risk management, aimed to determine flood magnitudes for varying return periods. This is, however, challenging in many developing and remote regions, including the Ogun-Osun River Basin of Nigeria due to the absence of sufficient historic hydrological data, due to financial, technical and organizational drawbacks.

We have presented a robust flood estimation approach based on L-moment regional flood frequency analysis that combines multiple short-length historical hydrological data to curb aleatoric uncertainty. Building on the evidence of climate influence on the changing hydrological regime in the region, this study accounts for climate variability effect on flood frequency estimates through climate indices.

Two homogeneous regions are identified based on clustering algorithm and statistical tests, while GLO three-parameter distribution is identified as the best fit distribution for flood frequency analysis in the 2 sub-regions based on L-moment ratio diagrams and goodness of fit test (Z-statistic). Also, Madden-Julian Oscillation (MJO) is identified as the most influential climate indices for the region, resulting in increased flood magnitude for direct and regional flood frequency estimates. This further reinforces the need to integrate climate variability into flood frequency analysis as more climate-driven events are expected due to global warming.

In conclusion, integrating climate variability into regional and direct flood frequency estimation results in more robust outcomes-a useful input into hydraulic modelling and flood risk mapping needed to inform resilient structural and non-structural flood risk management interventions. However, for the result of this study to be transferable to ungauged areas within the homogeneous regions, further analysis is needed to determine the physiographical parameters required to establish the best relationship with the index flood of sites in homogeneous sub-regions; for example, using approaches such as artificial neural networks (ANN)

\section{Acknowledgements}

The authors acknowledge the Niger Delta Development Commission (NDDC), Nigeria for funding Iguniwari Thomas Ekeu-wei's Ph.D. at Lancaster University, United Kingdom (NDDC/DEHSS/2013PGFS/BY/5), from which this paper is a product; we also acknowledge The Ogun Osun River Basin Authority (OORBA) for providing the in-situ river hydrological data. We appreciate the US Army Corps of Engineers provided free ICI-RAFT software license used for flood fre- 
quency analysis.

\section{Conflicts of Interest}

The authors declare no conflicts of interest regarding the publication of this paper.

\section{References}

[1] Tehrany, M.S., Pradhan, B. and Jebur, M.N. (2014) Flood Susceptibility Mapping Using a Novel Ensemble Weights-of-Evidence and Support Vector Machine Models in GIS. Journal of Hydrology, 512, 332-343. https://doi.org/10.1016/j.jhydrol.2014.03.008

[2] The Federal Government of Nigeria (2013) Post-Disaster Needs Assessment 2012 Floods.

https://www.gfdrr.org/sites/gfdrr/files/NIGERIA_PDNA_PRINT_05_29_2013_WE B.pdf

[3] Agada, S. and Nirupama, N. (2015) A Serious Flooding Event in Nigeria in 2012 with Specific Focus on Benue State: A Brief Review. Natural Hazards, 77, 1405-1414. https://doi.org/10.1007/s11069-015-1639-4

[4] Hosking, J.R.M. and Wallis, J.R. (1997) Regional Frequency Analysis: An Approach Based on L-Moments. Cambridge University Press, Cambridge, New York. https://doi.org/10.1017/CBO9780511529443

[5] Kjeldsen, T.R., Smithers, J.C. and Schulze, R.E. (2002) Regional Flood Frequency Analysis in the KwaZulu-Natal Province, South Africa, Using the Index-Flood Method. Journal of Hydrology, 255, 194-211. https://doi.org/10.1016/S0022-1694(01)00520-0

[6] Mishra, B., Takara, K., Yamashiki, Y. and Tachikawa, Y. (2009) Hydrologic Simulation-Aided Regional Flood Frequency Analysis of Nepalese River Basins. Journal of Flood Risk Management, 2, 243-253. https://doi.org/10.1111/j.1753-318X.2009.01041.x

[7] Ampadu, B., Chappell, N.A. and Kasei, R.A. (2013) Rainfall-River Flow Modelling Approaches: Making a Choice of Data-Based Mechanistic Modelling Approach for Data Limited Catchments: A Review. Canadian Journal of Pure and Applied Sciences, 7, 2571-2580.

[8] Olayinka, D.N., Nwilo, P.C. and Emmanuel, A. (2013) From Catchment to Reach: Predictive Modelling of Floods in Nigeria.

[9] Dano Umar, L., et al. (2011) Geographic Information System and Remote Sensing Applications in Flood Hazards Management: A Review. Research Journal of Applied Sciences, Engineering and Technology, 3, 933-947.

[10] Reed, D. (1999) Procedures for Flood Frequency Estimation, Volume 3: Statistical Procedures for Flood Frequency Estimation. Institute of Hydrology, Parker.

[11] Hrachowitz, M., et al. (2013) A Decade of Predictions in Ungauged Basins (PUB)-A Review. Hydrological Sciences Journal, 58, 1198-1255. https://doi.org/10.1080/02626667.2013.803183

[12] Wagener, T. (2007) Can We Model the Hydrological Impacts of Environmental Change? Hydrological Processes, 21, 3233-3236. https://doi.org/10.1002/hyp.6873

[13] Smith, A., Sampson, C. and Bates, P. (2015) Regional Flood Frequency Analysis at the Global Scale. Water Resources Research, 51, 539-553. 
https://doi.org/10.1002/2014WR015814

[14] Owe, M. and Neale, C. (2007) Remote Sensing for Environmental Monitoring and Change Detection (No. 316). International Assn of Hydrological Sciences.

[15] Kunkel, K. (2003) North American Trends in Extreme Precipitation. Natural Hazards, 29, 291-305. https://doi.org/10.1023/A:1023694115864

[16] Pettitt, A. (1979) A Non-Parametric Approach to the Change-Point Problem. Applied Statistics, 28, 126-135. https://doi.org/10.2307/2346729

[17] Kendall, M. and Stuart, A. (1969) The Advanced Theory of Statistics (Volume 1). Griffin, London.

[18] O'Brien, N.L. and Burn, D.H. (2014) A Nonstationary Index-Flood Technique for Estimating Extreme Quantiles for Annual Maximum Streamflow. Journal of $\mathrm{Hy}$ drology, 519, 2040-2048. https://doi.org/10.1016/j.jhydrol.2014.09.041

[19] Hounkpè, J., Diekkrüger, B., Badou, D.F. and Afouda, A.A. (2015) Non-Stationary Flood Frequency Analysis in the Ouémé River Basin, Benin Republic. Hydrology, 2, 210-229. https://doi.org/10.3390/hydrology2040210

[20] Li, J. and Tan, S. (2015) Nonstationary Flood Frequency Analysis for Annual Flood Peak Series, Adopting Climate Indices and Check Dam Index as Covariates. Water Resources Management, 29, 5533-5550. https://doi.org/10.1007/s11269-015-1133-5

[21] Adeaga, O., Oyebande, L. and Depraetere, C. (2006) Surface Runoff Simulation for Part of Yewa Basin. In: Predictions in Ungauged Basins. Promise and Progress, No. 303, IAHS Publ., Wallingford, 382.

[22] Adeleke, O.O., Makinde, V., Eruola, A.O., Dada, O.F., Ojo, A.O. and Aluko, T.J. (2015) Estimation of Groundwater Recharges Using Empirical Formulae in Odeda Local Government Area, Ogun State, Nigeria. Challenges, 6, 271-281.

https://doi.org/10.3390/challe6020271

[23] Komolafe, A.A., et al. (2015) A Review of Flood Risk Analysis in Nigeria. American Journal of Environmental Sciences, 11, 157-166. https://doi.org/10.3844/ajessp.2015.157.166

[24] Mouhamed, L., Traore, S.B., Alhassane, A. and Sarr, B. (2013) Evolution of Some Observed Climate Extremes in the West African Sahel. Weather and Climate $E_{X-}$ tremes, 1, 19-25. https://doi.org/10.1016/j.wace.2013.07.005

[25] New, M., et al. (2006) Evidence of Trends in Daily Climate Extremes over Southern and West Africa. Journal of Geophysical Research: Atmospheres, 111, D14102. https://doi.org/10.1029/2005JD006289

[26] Diatta, S. and Fink, A.H. (2014) Statistical Relationship between Remote Climate Indices and West African Monsoon Variability. International Journal of Climatology, 34, 3348-3367. https://doi.org/10.1002/joc.3912

[27] Salau, O.R., Fasuba, A., Aduloju, K.A., Adesakin, G.E. and Fatigun, A.T. (2016) Effects of Changes in ENSO on Seasonal Mean Temperature and Rainfall in Nigeria. Climate, 4, 5. https://doi.org/10.3390/cli4010005

[28] Olukanni, D. and Alatise, M. (2008) Rainfall-Runoff Relationships and Flow Forecasting, Ogun River Nigeria. Journal of Environmental Hydrology, 16, 1-12.

[29] Ewemoje, T.A. and Ewemooje, O. (2011) Best Distribution and Plotting Positions of Daily Maximum Flood Estimation at Ona River in Ogun-Oshun River Basin, Nigeria. Agricultural Engineering International: CIGR Journal, 13, 1-10.

[30] Rohatgi, A. (2017) Web Plot Digitizer. https://automeris.io/WebPlotDigitizer

[31] Farr, T.G., et al. (2007) The Shuttle Radar Topography Mission. Reviews of Geo- 
physics, 45, RG2004. https://doi.org/10.1029/2005RG000183

[32] GCOS-AOPC/PPOC. Download Climate Time Series. http://www.esrl.noaa.gov/psd/gcos_wgsp/Timeseries

[33] Ekeu-wei, I.T., Blackburn, G.A. and Pedruco, P. (2018) Infilling Missing Data in Hydrology: Solutions Using Satellite Radar Altimetry and Multiple Imputation for Data-Sparse Regions. Water, 10, 1483. https://doi.org/10.3390/w10101483

[34] Mann, H.B. (1945) Nonparametric Tests against Trend. Econometrica: Journal of the Econometric Society, 13, 245-259. https://doi.org/10.2307/1907187

[35] Yue, S. and Wang, C. (2002) The Influence of Serial Correlation on the MannWhitney Test for Detecting a Shift in Median. Advances in Water Resources, 25, 325-333. https://doi.org/10.1016/S0309-1708(01)00049-5

[36] Stedinger, J.R. (1983) Estimating a Regional Flood Frequency Distribution. Water Resources Research, 19, 503-510. https://doi.org/10.1029/WR019i002p00503

[37] Pedruco, P., Nielsen, C., Kuczera, G. and Rahman, A. (2014) Combining Regional Flood Frequency Estimates with an at Site Flood Frequency Analysis Using a Bayesian Framework: Practical Considerations. In: Hydrology and Water Resources Symposium, ACT: Engineers Australia, Barton, 766-773.

[38] Grubbs, F.E. and Beck, G. (1972) Extension of Sample Sizes and Percentage Points for Significance Tests of Outlying Observations. Technometrics, 14, 847-854. https://doi.org/10.1080/00401706.1972.10488981

[39] Kwon, H.H., Brown, C. and Lall, U. (2008) Climate Informed Flood Frequency Analysis and Prediction in Montana Using Hierarchical Bayesian Modeling. Geophysical Research Letters, 35, L05404. https://doi.org/10.1029/2007GL032220

[40] Gutiérrez, F. and Dracup, J.A. (2001) An Analysis of the Feasibility of Long-Range Streamflow Forecasting for Colombia Using El Niño-Southern Oscillation Indicators. Journal of Hydrology, 246, 181-196. https://doi.org/10.1016/S0022-1694(01)00373-0

[41] Sayers, P., et al. (2015) Strategic Flood Management: Ten “Golden Rules” to Guide a Sound Approach. International Journal of River Basin Management, 13, 137-151. https://doi.org/10.1080/15715124.2014.902378

[42] Machado, M.J., Botero, B.A., López, J., Francés, F., Díez-Herrero, A. and Benito, G. (2015) Flood Frequency Analysis of Historical Flood Data under Stationary and Non-Stationary Modelling. Hydrology and Earth System Sciences Discussions, 12, 525-568. https://doi.org/10.5194/hessd-12-525-2015

[43] Giovannettone, J.P. (2015) Correlating MJO Activity with Argentina Rainfall and Atlantic Hurricanes Using ICI-RAFT. Journal of Hydrologic Engineering, 22, E5015004.

[44] Giovannettone, J. and Wright, M. (2011) The ICI-WARM Non-Proprietary Regional Frequency Analysis Tool Using the Method of L-Moments. AGU Fall Meeting, Vol. 1, 1016.

[45] Dalrymple, T. (1960) Flood-Frequency Analyses, Manual of Hydrology: Part 3. USGPO.

[46] Padi, P.T., Baldassarre, G.D. and Castellarin, A. (2011) Floodplain Management in Africa: Large Scale Analysis of Flood Data. Physics and Chemistry of the Earth, 36, 292-298. https://doi.org/10.1016/j.pce.2011.02.002

[47] Izinyon, O. and Ajumka, H. (2013) Regional Flood Frequency Analysis of Catchments in Upper Benue River Basin Using Index Flood Procedure. Nigerian Journal of Technology, 32, 159-169. 
[48] Stedinger, J.R. and Griffis, V.W. (2008) Flood Frequency Analysis in the United States: Time to Update. Journal of Hydrologic Engineering, 13, 199-204. https://doi.org/10.1061/(ASCE)1084-0699(2008)13:4(199)

[49] Izinyon, O. and Ehiorobo, J. (2014) L-Moments Approach for Flood Frequency Analysis of River Okhuwan in Benin-Owena River Basin in Nigeria. Nigerian Journal of Technology, 33, 10-18. https://doi.org/10.4314/njt.v33i1.2

[50] Komi, K., Amisigo, B.A., Diekkrüger, B. and Hountondji, F.C. (2016) Regional Flood Frequency Analysis in the Volta River Basin, West Africa. Hydrology, 3, 5. https://doi.org/10.3390/hydrology3010005

[51] Adeaga, O. (2006) Multi-Decadal Variability of Rainfall and Water Resources in Nigeria. In: Climate Variability and Change-Hydrological Impacts, IAHS Publication No. 308, Wallingford, 294.

[52] Oyegoke, S. and Oyebande, L. (2008) A New Technique for Analysis of Extreme Rainfall for Nigeria. Environmental Research Journal, 2, 7-14.

[53] Federal Ministry of Environment (2005) Technical Guidelines on Soil Erosion, Flood and Coastal Zone Management.

[54] Peel, M., Wang, Q.J., Vogel, R. and McMahon, T. (2001) The Utility of L-Moment Ratio Diagrams for Selecting a Regional Probability Distribution. Hydrological Sciences Journal, 46, 147-155. https://doi.org/10.1080/02626660109492806

[55] Hailegeorgis, T.T. and Alfredsen, K. (2017) Regional Flood Frequency Analysis and Prediction in Ungauged Basins Including Estimation of Major Uncertainties for Mid-Norway. Journal of Hydrology: Regional Studies, 9, 104-126.

https://doi.org/10.1016/j.ejrh.2016.11.004

[56] Leclerc, M. and Ouarda, T.B.M.J. (2007) Non-Stationary Regional Flood Frequency Analysis at Ungauged Sites. Journal of Hydrology, 343, 254-265.

https://doi.org/10.1016/j.jhydrol.2007.06.021

[57] Hall, J., et al. (2014) Understanding Flood Regime Changes in Europe: A State-of-the-Art Assessment. Hydrology and Earth System Sciences, 18, 2735-2772. https://doi.org/10.5194/hess-18-2735-2014

[58] Madden, R.A. and Julian, P.R. (1971) Detection of a 40-50 Day Oscillation in the Zonal Wind in the Tropical Pacific. Journal of the Atmospheric Sciences, 28, 702-708. https://doi.org/10.1175/1520-0469(1971)028<0702:DOADOI >2.0.CO;2

[59] Mohino, E., Janicot, S., Douville, H. and Li, L. (2012) Impact of the Indian Part of the Summer MJO on West Africa Using Nudged Climate Simulations. Climate Dynamics, 38, 2319-2334. https://doi.org/10.1007/s00382-011-1206-y

[60] Lavender, S.L. and Matthews, A.J. (2009) Response of the West African Monsoon to the Madden-Julian Oscillation. Journal of Climate, 22, 4097-4116. https://doi.org/10.1175/2009JCLI2773.1

[61] ACMAD (2012) Flood Report over West Africa-September 2012. African Centre of Meteorological Applications for Development (ACMAD). http://reliefweb.int/sites/reliefweb.int/files/resources/FloodreportoverWestAfrica.pdf

[62] Arnold, N., Branson, M., Kuang, Z., Randall, D. and Tziperman, E. (2015) MJO Intensification with Warming in the Superparameterized CESM. Journal of Climate, 28, 2706-2724. https://doi.org/10.1175/JCLI-D-14-00494.1

[63] Caballero, R. and Huber, M. (2010) Spontaneous Transition to Superrotation in Warm Climates Simulated by CAM3. Geophysical Research Letters, 37, L11701. https://doi.org/10.1029/2010GL043468

[64] Sheng, H., et al. (2020) Frequency and Magnitude Variability of Yalu River Flood- 
ing: Numerical Analyses for the Last 1000 Years. Hydrology and Earth System Sciences. https://doi.org/10.5194/hess-2019-582

[65] López, J. and Francés, F. (2013) Non-Stationary Flood Frequency Analysis in Continental Spanish Rivers, Using Climate and Reservoir Indices as External Covariates. Hydrology and Earth System Sciences, 17, 3189-3203.

https://doi.org/10.5194/hess-17-3189-2013

[66] Serinaldi, F., Kilsby, C.G. and Lombardo, F. (2018) Untenable Nonstationarity: An Assessment of the Fitness for Purpose of Trend Tests in Hydrology. Advances in Water Resources, 111, 132-155. https://doi.org/10.1016/j.advwatres.2017.10.015 